\title{
Proses Kemampuan Berpikir Kreatif Siswa Matematika Berdasarkan Masalah Open-Ended pada Materi Bangun Datar
}

\author{
Dian Putri Wulandari ${ }^{1}$, Susiswo ${ }^{2}$, dan I Made Sulandra ${ }^{3}$ \\ ${ }^{1,2,3}$ Program Studi Pendidikan Matematika, Fakultas Matematika dan Ilmu Pengetahuan Alam, Universitas Negeri Malang, \\ Jl. Semarang 5, Malang, Indonesia \\ dianawulandari26@gmail.com
}

\begin{abstract}
Creative thinking is a matter in mathematics. Most teachers in school are still inattentive this skill. Creative thinking skill and knowing students creative thinking process can make teacher getting broad insights about students' potency. This research is aimed to find out students creative thinking process and students' ability through open-ended problem. The subject categories are a) students with high ability of creative thinking; b) students with average ability of creative thinking; and c) students with low ability of creative thinking. Creative thinking indicators includes fluency, flexibility, and novelty. Meanwhile the stages of creative thinking are 1) being aware of problem occurring, 2) understanding the problem, 3) making speculation and formulating the hypothesis; 4) testing and evaluating the hypothesis; and 5) communicating the idea. The method used in this research was qualitative research approach. The data were collected from students' answers and interview result. The research was conducted in class VII of An-Nur Junior High School with the amount of 29 students. The result of this research is students creative thinking process which is categorized 3 students with high ability of creative thinking, 12 students with average ability of creative thinking, and 14 students with low ability of creative thinking
\end{abstract}

Keywords: creative thinking ability, creative thinking process, and open-ended problem

\begin{abstract}
Abstrak
Berpikir kreatif adalah masalah penting dalam pembelajaran matematika. Sebagian besar guru di sekolah kurang memperhatikan kemampuan tersebut. Kemampuan berpikir kreatif dan mengetahui proses berpikir kreatif siswa mengakibatkan guru memperoleh pengetahuan yang luas terhadap potensi yang siswa miliki. Tujuan Penelitian ini yaitu mengetahui proses berpikir kreatif dan kemampuan siswa melalui masalah open-ended. Kriteria subjek dapat dikategorikan sebagai a) siswa memiliki kemampuan berpikir kreatif tinggi; b) siswa memiliki kemampuan berpikir kreatif sedang; dan c) siswa memiliki kemampuan berpikir kreatif rendah. Kemudian indikator kemampuan berpikir kreatif pada penelitian ini yaitu kelancaran (fluency), fleksibilitas (fexibelity), dan kebaruan (novelty) sementara tahap proses berpikir kreatif yaitu; 1) mengetahui adanya masalah;2) memahami masalah; 3) membuat dugaan dan merumuskan hipotesis; 4) menguji hipotesis dan mengevaluasi; dan 5) mengkomunikasikan ide. Metode penelitian ini menggunakan pendekatan kualitatif. Data diperoleh dari jawaban siswa dan hasil wawancara. Penelitian dilakukan di kelas VII SMP An-Nur dengan jumlah siswa sebanyak 29 siswa. Hasil dari penelitian ini yaitu berupa proses berpikir kreatif siswa, 3 siswa dikategorikan sebagai kemampuan tinggi, 12 siswa memiliki kemampuan sedang, dan 14 siswa berkemampuan rendah.
\end{abstract}

Kata kunci: kemampuan berpikir kreatif, proses berpikir kreatif, masalah open-ended

Copyright (c) 2021 Dian Putri Wulandari, Susiswo, I Made Sulandra

$\triangle$ Corresponding author: Dian Putri Wulandari

Email Address: dianawulandari26@gmail.com (Rt 27 Rw 12, Bendorejo, Pogalan Trenggalek)

Received 09 July 2021, Accepted 15 July 2021, Published 02 August 2021

\section{PENDAHULUAN}

Bloom menyusun taksonomi tujuan pendidikan dimana suatu kerangka untuk menglasifikasikan hasil pembelajaran yang diharapkan untuk dicapai oleh siswa (Krathwohl, 2002). Kemudian taksonomi Bloom direvisi oleh Anderson dan Krathwohl yang memberikan dimensi baru yaitu mengingat (remember), memahami (understand), menerapkan (apply), menganalisis (analyse), mengevaluasi (evaluate), dan menciptakan (create). Taksonomi ini memiliki tujuan yaitu menciptakan dan membutuhkan kemampuan berpikir kreatif untuk mencapainya. Kemampuan berpikir kretif dibutuhkan 
oleh siswa di masa depan. Menurut Sriraman, dkk (2011), kreatifitas memiliki fungsi penting pada siklus berpikir matematis. Faktanya, sebagian besar guru SD sampai SMA belum memperhatikan kemampuan berpikir kreatif siswa didiknya.

Berpikir kreatif masih menjadi topik yang menarik untuk diteliti. Membuat desain pembelajara yang dapat memberikan siswa kesempatan untuk memperdalam masalah yang memberikan banyak solusi dapat meningkatkan kemampuan berpikir kreatif siswa (Silver, 1997; Hamza and Griffith, 2006). Menurut Mahmudi (2010), megidentifikasi kemampuan berpikir kreatif siswa dapat dilakukan dengan mengembangkan soal. Sehingga dengan membandingkan dan membuat hubungan antara kemampuan berpikir kreatif dengan ketrampilan yang lain dapat memperbanyak wawasan guru untuk mengetahui potensis yang dimiliki oleh siswanya (Fajriah dan Asiskawati, 2015).

Haylock (1997) membagi menjadi dua pendekatan utama berpikir kreatif yaitu, proses dan produk. Dilihat dari sisi proses berpikir kreatif merupakan respon siswa dalam menyelesaikan masalah dengan menggunakan metode sesuai. Pada penelitian ini, proses berpikir kreatif diawali dari siswa mengetahui permasalahan, sampai dengan mengkomunikasikan hasil idenya. Dari sisi produk, Isaksen, dkk (1993)menguraikan bahwa berpikir kreatif memfokuskan pada aspek kelancaran (fluency), keluwesan (flexibility), kebaruan (novelty), dan keterincian (elaboration). Aspek kelancaran dapat diidentifikasikan dari banyaknya respon siswa yang relevan. Respon-respon siswa tersebut dapat dikategorikan menjadi beberapa kategori yang terkait dengan aspek keluwesan. Kemungkinan respon yang diberikan siswa banyak tetapi hanya merupakan satu kategori. Kemudian resppon siswa dapat dikatakan baru jika respon tersebut unik, tidak biasa, dan hanya dilakukan oleh beberapa siswa. Respon tersebut dikatakan rinci apabila memiliki prosedur yang runtut, logis, dan jelas.

Berpikir kreatif yaitu sebagai proses dari: 1) mengetahui adanya masalah, 2) memahami masalah, 3) membuat dugaan dan merumuskan hipotesis, 4) menguji hipotesis dan evaluasi, 5) mengkomunikasikan hasilnya (Febrianti, dkk 2016). Krathwohl dan Anderson di dalam taksonomi Bloom merangkum proses kognitif dari aspek mencipta yaitu membangun ide (generating), merencanakan penyelesaian (planning), dan menghasilkan solusi (producing). Aspek-aspek proses berpikir kreatif yang dideskripsikan oleh Torrance dan berdasarkan Taksonomi Bloom terevisi saling terkait satu sama lain (Anderson, L dan Krathwohl, R 1956).

Tabel 1. Perbandingan dan hubungan antara proses berpikir kreatif oleh Torrance dan Taksonomi Bloom (terevisi)

\begin{tabular}{|l|l|}
\hline \multicolumn{1}{|c|}{ Torrance } & \multicolumn{1}{c|}{ Taksonomi Bloom (terevisi) } \\
\hline $\begin{array}{l}\text { Mengetahui adanya masalah, kesenjangan } \\
\text { informasi, adanya unsur yang hilang } \\
\text { Memahami masalah }\end{array}$ & $\begin{array}{l}\text { Representasi masalah, dimana siswa mencoba } \\
\text { memahami masalah dan membangun berbagai } \\
\text { solusi yang mungkin (generating) }\end{array}$ \\
\hline Membuat dugaan dan menyusun hipotesis & $\begin{array}{l}\text { Perencanaan solusi, dimana siswa mengecek } \\
\text { kemungkinan-kemungkinan dan menyusun } \\
\text { rencana yang bisa diterapkan (planning) }\end{array}$ \\
\hline Menguji dan mengevaluasi & $\begin{array}{l}\text { Eksekusi penyelesaian, dimaan siswa dengan } \\
\text { baik melaksanakan rencana dan memperoleh } \\
\text { solusi (producing) }\end{array}$ \\
\hline Mengkomunikasikan hasil &
\end{tabular}


Sebagian peneliti menggunakan soal berpikir kreatif seperti TTCT (Torrance Test of Creative Thinking), CAMT (Creative Ability in Mathematical Test), dan alat ukur lainnya. Sedangkan Getzel dan Jackson menggunakan soal yang mempunyai banyak jawaban atau banyak cara penyelesaian (Silver, 1997). Krulik dan Rudnick (1995) berpendapat bahwa masalah merupakan situasi yang membutuhkan pemikiran dari pengetahuan yang dipelajari sebelumnya untuk menyelesaikannya. Sehingga, sesorang perlu mencoba cara lain apabila cara pertama yang diambil belum menyelesaikan masalah tersebut (Hudojo, 2005). Dengan demikian, sesuatu akan menjadi masalah bagi sesorang apabila tidak dapat mengetahui secara langsung cara apa yang dapat digunakan dalam menyelesaikan masalah tersebut. Hudojo (2005) menyatakan syarat masalah jika pertanyaan yang dihadapkan kepada siswa harus dapat dimengerti oleh siswa, namun pertanyaan tersebut harus merupakan tantangan bagi siswa untuk menjawabnya dan pertanyaan tersebut tidak bisa dijawab menggunakan prosedur rutin yang telah diketahui siswa.

Masalah open-ended merupakan permasalahan yang memiliki ragam jawaban yang benar (Magelo, dkk, 2019). Kemudian Keh, dkk (2019) menyatakan bahwa pembelajaran open-ended yaitu pembelajaran yang dimulai dari mempresentasikan masalah open-ended, kemudiian memiliki tujuan untuk memberikan pengalaman untuk siswa menemukan hal baru. Masalah open-ended yaitu memiliki karakteristik seperti pertanyaan yang melibatkan informasi matematis yang penting, menimbulkan respon bervariasi, memerlukan komunikasi, diutarakan dengan jelas, dan menggunakan rubrik pensekoran (Bulkova dan Ceretkova, 2017).

\section{METODE}

Penelitian ini menggunakan pendekatan kualitatif. Data yang diperoleh berasal dari jawaban siswa dan hasil wawancara. Teknik menentukan sampel penelitian yaitu dengan snowball sampling, dimana memilih siswa dengan kemampuan tinggi, sedang dan rendah. Kategori tersebut ditentukan oleh kemampuan siswa dalam memberikan respon soal open-ended berdasarkan kriteria kelancaran (fluency), fleksibelitas (flexibility), dan kebaruan (novelty). Penelitian dilakukan di kelas VII SMP An-Nur dengan jumlah siswa sebanyak 29 siswa.

Langkah-langkah pada penelitian ini adalah: 1) menentukan kelas yang pernah mendapatkan pembelajaran open-ended, 2) memberikan siswa soal kemampuan berpikir kreatif menggunakan pertanyaan open-ended, 3) menentukan subjek wawancara tentang kemampuan berpikir kreatif dengan mengelompokkan siswa sebagai tinggi, sedang, dan rendah, 4) melakukan wawancara untuk mengetahui proses berpikir kreatif siswa yang meliputi: mengidentifikasi dan memahami masalah, membuat dugaan dan merumuskan masalah, membuat dugaan dan merumuskan hipotesis, mengevaluasi dan menguji hipotesis, dan mengkomunikasikan hasilnya. Tugas pertama siswa adalah gambar seperti di bawah ini disertai dengan dua pertanyaan seperti berikut. 


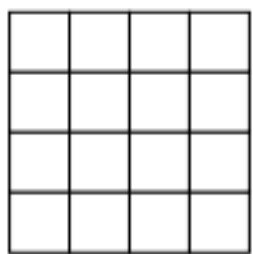

Gambar 1. Pesegi Berukuran 1 Satuan Permasalahan Satu

a. Berapakah persegi yang dapat kamu temukan dari gambar di atas?

b. Berapakah persegi panjang yang dapat ditemukan dari gambar di atas?

Siswa dapat dikategorikan tinggi apabila dapat mengetahui bahwa pada gambar tersebut terdapat 16 buah persegi memiliki ukuran sisi 1 satuan panjang, 9 buah persegi yang memiliki ukuran 2 satuan panjang, 4 buah persegi ukuran sisi 3 satuan panjang, dan 1 buah persegi dengan panjang sisi sebanyak 4 satuan panjang. Sedangkan persegi panjang memiliki 70 jenis yaitu berukuran $1 \times 2$ sebanyak 24 buah, 1x3 sebanyak 16 buah, $1 \times 4$ sebanyak 8 buah, $2 \times 3$ sebanyak 12 buah, $2 \times 4$ sebanyak 6 buah, dan $3 \times 4$ sebanyak 4 buah.

Permasalahan kedua yaitu, sebuah bangun datar berbentuk persegi panjang dapat terbentuk dari bangun datar lainnya. Misalnya sebuah persegi panjang dapat dibentuk dari dua segitiga siku-siku dan sebuah segitiga tumpul seperti pada gambar di bawah ini.

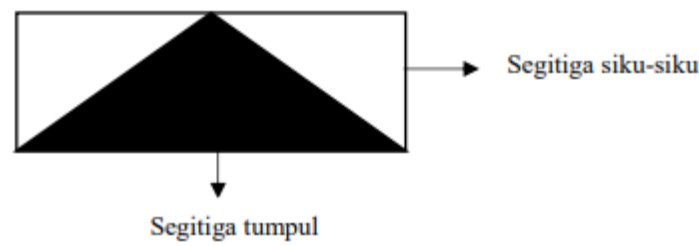

Gambar 2. Persegi Panjang Terbentuk Dari Segitiga Siku-Siku Dan Tumpul

Tugas yang diberikan kepada siswa adalah membuat bangun datar berbentuk persegi panjang serta bangun penyusunnya sebanyak mungkin seperti yang dicontohkan. Dari tugas tersebut siswa diharapkan dapat menggambarkan bangun datar yang terbentuk dari bangun datar lainnya disertai dengan nama bangun penyusunnya.

\section{HASIL DAN DISKUSI}

Hasil penelitian setelah siswa diberikan soal tersebut, diperoleh 3 siswa dikategorikan sebagai kemampuan tinggi, 12 siswa memiliki kemampuan sedang, dan 14 siswa berkemampuan rendah. Setiap kategori diambil dua siswa berkemampuan tinggi yaitu S1 dan S2. Siswa berkemampan sedang yaitu S3 dan S4. Sedangkan siswa berkemampuan rendah yaitu S5 dan S6.

Permasalahan pertama membutuhkan ketelitian dan kerincian untuk memperoleh jawaban seluruh jumlah persegi dan persegi panjang. Beberapa dari mereka ada yang benar-benar memahami permasalahan yang diberikan, namun ketika menghitung mereka tidak teliti. Siswa berkemampuan tinggi yaitu S1 dan S2 mengetahui bahwa persegi yang dimaksud tidak hanya yang terdapat pada soal yaitu gambar 16 persegi dengan ukuran 1 satuan. Siswa tersebut mengenali bahwa pada gambar terdapat 
persegi dengan luas 4 satuan, 9 satuan, dan 16 satuan seperti pada gambar.

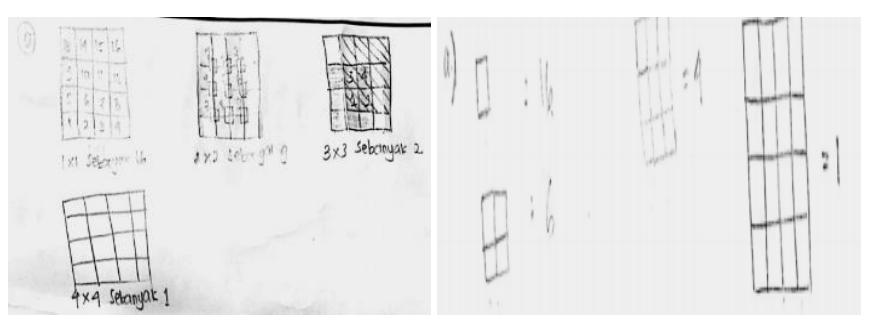

Gambar 3. Jawaban S1(kiri) dan S2 (kanan) pada permasalahan 1

S1 dan S2 menemukan beberapa persegi panjang yang terbentuk pada soal tersebut yang ditunjukkan pada gambar dibawah ini.

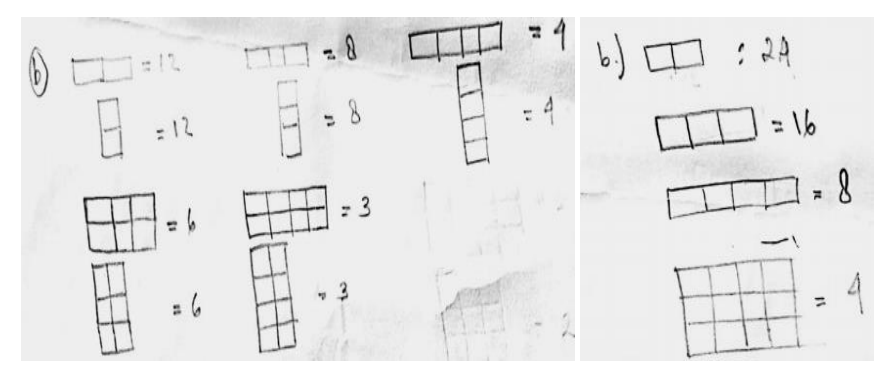

Gambar 4. Jawaban S1(kiri) dan S2 (kanan) Pada Permasalahan 1

Siswa yang memiliki kemampuan sedang menemukan ada persegi lain selain 16 persegi berukuran 1 satuan pada soal, namun tidak dapat menyebutkan jumlah persegi dengan lengkap. Siswa S3 dan S4 dapat menemukan persegi dengan luas 1 satuan, 4 satuan, dan 16 satuan, namun mereka tidak menemukan persegi dengan luas 9 satuan seperti pada gambar dibawah ini.

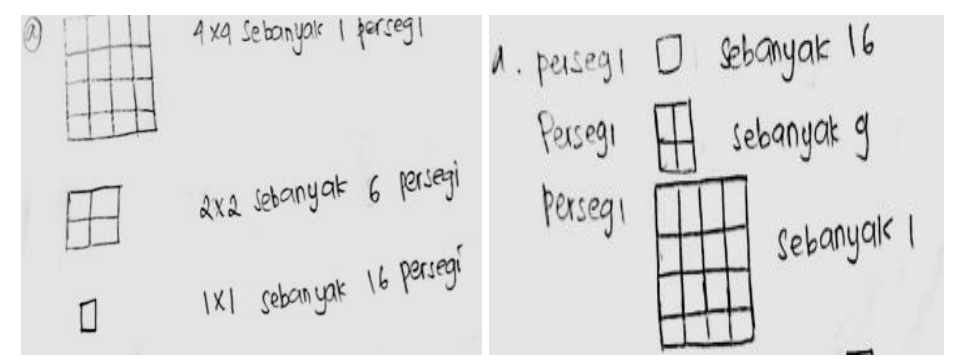

Gambar 5. Jawaban S3 (kiri) dan S4 (kanan) Pada Permasalahan 1

S3 dan S4 juga menemukan beberapa persegi panjang yang dapat dibentuk pada soal tersebut. Beberapa ditunjukkan pada gambar

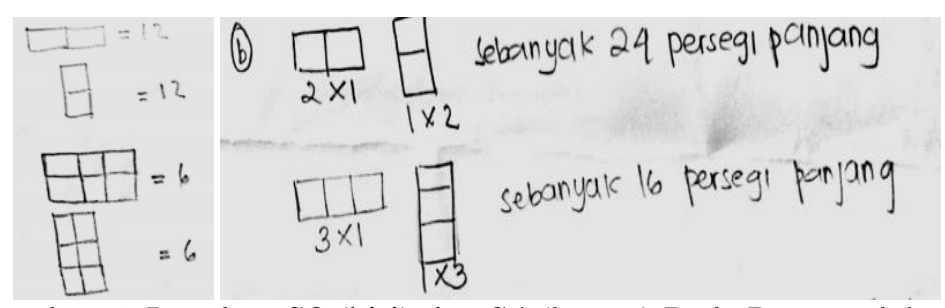

Gambar 6. Jawaban S3 (kiri) dan S4 (kanan) Pada Permasalahan 1 
Siswa yang memiliki kemampuan rendah hanya dapat mengenali lias persegi 1 satuan dan 16 satuan. Sebagian besar dari siswa berkemampuan rendah hanya mampu menemukan luas persegi 1 satuan sebanyak 16 persegi. Permasalahan kedua siswa berkemampuan tinggi yaitu S1 mampu membuat 10 kombinasi bangun datar penyusun persegi panjang. Terdapat 3 gambar dari 10 gambar yang S1 berikan berbeda dengan siswa lainnya dan sisanya jawaban tersebut hampir sama dengan siswa lainnya. S1 dapat member nama pada bangun datar penyusun tersebut dengan lengkap dan tepat. S2 dapat membuat 8 jenis kombinasi bangun datar penyusun persegi panjang dan 4 diantara 8 jawabannya berbeda dengan siswa lainnya.
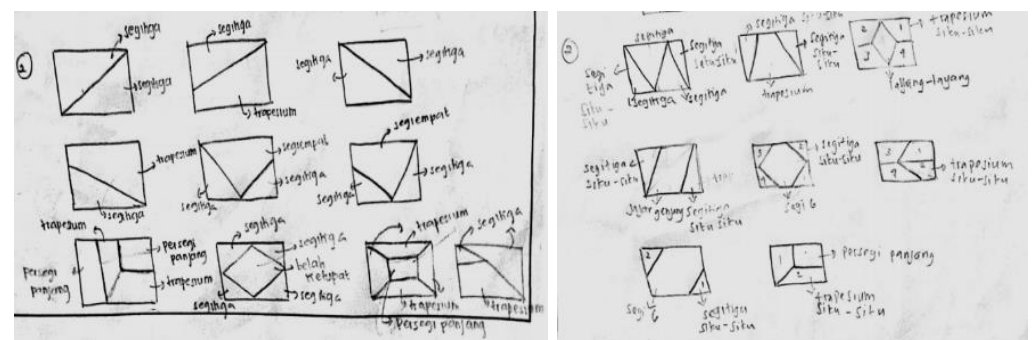

Gambar 7. Jawaban S1 (kiri) dan S2 (kanan) pada permasalahan 2

Siswa berkemampuan sedang memberikan respon rata-rata menjawab 3 hingga 4 jenis kombinasi bangun datar penyusun persegi panjang. Respon yang diberikan siswa tersebut hampir sama dengan siswa lainnya. S3 membuat 4 jenis kombinasi dan S4 membuat 3 jenis kombinasi bangun datar penyusun persegi panjang yang hampir sama. mereka memberikan nama bangun penyusun persegi panjang dengan tidak lengkap.

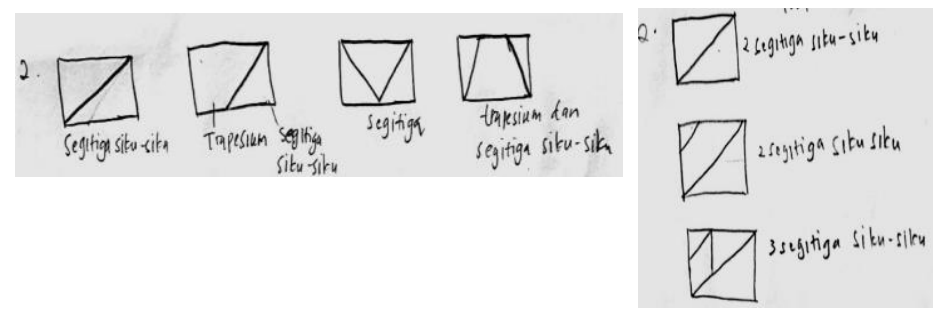

Gambar 8. Jawaban S3 (kiri) dan S4 (kanan) Pada Permasalahan 2

Siswa berkemampuan rendah yaitu S5 dan S6 menjawab 1 jenis kombinasi bangun datar penyusun persegi panjang. Mereka juga melakukan kesalahan saat memberikan nama bangun penyusun persegi panjang bahkan ada yang tidak diberikan nama bangun penyusunnya.

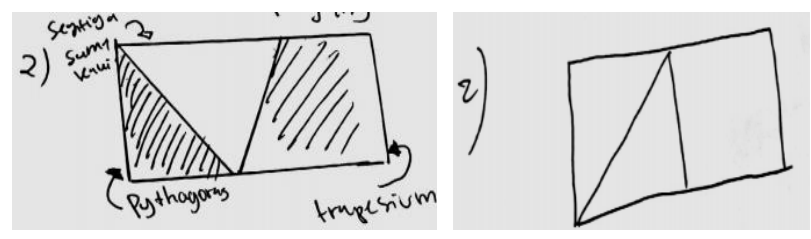

Gambar 9. Jawaban S5 (kiri) dan S6 (kanan) Pada Permasalahan 2 
Wawancara dilakukan dalam rangka mengetahui proses berpikir kreatif siswa. Kegiatan tersebut bertujuan untuk melihat kembali apakah mereka menulis sesuai dengan yang mereka pikirkan. Siswa kategori tinggi yaitu S1 dan S2, langsung memahami soal ketika diberikan. Siswa kategori ini langsung membuat rencana untuk menggambar kombinasi bangun datar penyusun persegi panjang dengan membuat persegi panjang terlebih dahulu. Kemudian mereka membagi persegi panjang menjadi bangun datar lainnya. Setelah itu S1 dan S2 memberikan nama pada bangun datar penyusun persegi panjang tersebut

S3 dan S4 yang merupakan siswa berkemampuan sedang, pada awalnya belum memahami permasalahan. Mereka harus membaca lebih dari satu kali dan melihat contoh baru mereka memahami perintah soal. Siswa berkemampuan rendah yaitu S5 dan S6 tidak memahami apa yang dimaksud pada soal. S5 dan S6 membutuhkan bantuan guru untuk memahami maksud soal. Ketika wawancara peneliti memberikan pertanyaan mengapa tidak menuliskan nama bangun datar penyusun persegi panjang dengan lengkap. S5 menjawab karena kehabisan waktu, sedangkan S6 dalam memberikan nama bangun datar penyusun persegi panjang tersebut masih ragu sehingga tidak menuliskannya. Ketika peneliti meminta menyebutkan nama bangun datar penyusun persegi panjang yang dibuat pada lembar jawaban, mereka sering salah dalam menyebut nama bangun datar yang ditunjuk oleh peneliti. S5 menyebutkan segitiga sama kaki pada segitiga siku-siku sama kaki dan menyebut segitiga tumpul sebagai segitiga sama sisi. S6 menyebutkan persegi segabai jajargenjang dan segitiga lancip sebagai segitiga siku siku sama sisi.

Berdasarkan data penelitian yang diperoleh, peneliti menyusun pola pikir kreatif siswa dari sisi proses dan produk untuk setiap kategori setelah pemberian soal open-ended pada Tabel 2 berikut ini.

Tabel 2. Proses dan Produk Berpikir Kreatif Kategori Tinggi, Sedang, Rendah

\begin{tabular}{|c|c|c|}
\hline Kategori & Proses Berpikir Kreatif & Hasil Berpikir Kreatif \\
\hline Tinggi & $\begin{array}{l}\text { Siswa kategori ini mampu } \\
\text { memahami masalah dan dapat } \\
\text { memperkirakan solusinya, lalu } \\
\text { melaksanakan rencana, } \\
\text { kemudian mengevaluasi ketika } \\
\text { terjadi kendala ketika } \\
\text { memperoleh solusi. Siswa } \\
\text { dapat mengkomunikasikan ide } \\
\text { secara lisan dan tertulis dengan } \\
\text { runtut dan jelas. }\end{array}$ & $\begin{array}{l}\text { Siswa kategori ini memiliki } \\
\text { produk berpikir kreatif yang } \\
\text { bermacam-macam, bahkan } \\
\text { respon yang siswa berikan juga } \\
\text { beragam dibandingkan dengan } \\
\text { yang lain dan hasil yang } \\
\text { mereka berikan cukup lengkap } \\
\text { dan jelas. }\end{array}$ \\
\hline Sedang & $\begin{array}{l}\text { Siswa kategori ini mampu } \\
\text { memahami masalah yang } \\
\text { diberikan, memperkirakan } \\
\text { solusi, menyusun rencana, dan } \\
\text { melaksanakan rencana } \\
\text { tersebut, tetapi siswa kategori } \\
\text { ini cenderung mudah menyerah } \\
\text { ketika menemui rintangan } \\
\text { dalam menjalankan rencana } \\
\text { mereka bahkan membatalkan }\end{array}$ & $\begin{array}{l}\text { Siswa kategori sedang } \\
\text { memiliki produk berpikin } \\
\text { kreatif kurang bervariasi ketika } \\
\text { merespon suatu permasalahan. } \\
\text { Beberapa respon tersebut sama } \\
\text { dengan siswa lainnya, jawaban } \\
\text { yang mereka berikanpun } \\
\text { kurang lengkap dan rinci. }\end{array}$ \\
\hline
\end{tabular}




\begin{tabular}{|c|c|c|}
\hline & $\begin{array}{l}\text { prosedur yang sudah mereka } \\
\text { susun. }\end{array}$ & \\
\hline Rendah & $\begin{array}{l}\text { Siswa kategori ini tidak } \\
\text { mampu memahami masalah } \\
\text { dan kesulitan menafsirkan } \\
\text { solusinya. Ketika menyusun } \\
\text { rencana siswa kategori rendah, } \\
\text { tidak mengetahui cara yang } \\
\text { mereka berikan sudah benar } \\
\text { atau tidak. }\end{array}$ & 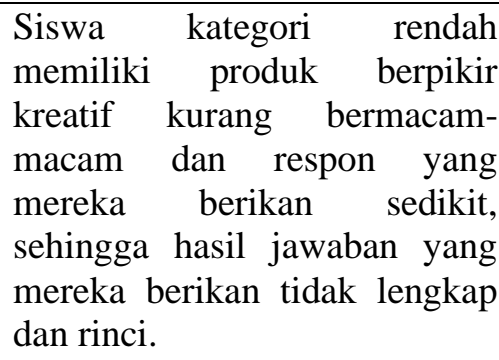 \\
\hline
\end{tabular}

Proses berpikir kreatif lebih mudah dilakukan apabila siswa memiliki pengalaman belajar dengan baik (Putri dan Wijayanti, 2013). Sebagaimana yang terlihat pada Tabel 2, siswa kategori tinggi sampai dengan rendah memiliki perbedaan yang signifikan dalam menyampaikan idenya. Ide-ide tersebut diperoleh dari pengalaman belajar di kelas yang diingatnya dan melakukan pemikiran secara mendalam. Proses berpikir kreatif yang ditunjukkan pada siswa kategori rendah menujukkan bahwa ia belum mampu memahi masala, menafsirkan solusi, dan rencana yang disusun belum baik. Hal ini berimplikasi pada hasil berpikir kreatif siswa kategori rendah dengan tidak memberikan banyak respon yang diharapkan. Berbeda dengan siswa kategori sedang meskipun mampu memahami masalah dengan baik tetapi siswa kategori ini cenderung mudah menyerah sehingga memiliki produk yang kurang bervariasi. Siswa berkatogori tinggi mampu memahami masalah serta menyelesaikan masalah dengan baik sehingga produk yang dihasilkan bervariasi secara jelas dan rinci.

Penelitian ini memiliki implikasi umum bahwa pembelajaran matematika apabila menekankan pada meningkatkan kemampuan berpikir kreatifnya, maka perlu juga diperhatikan bagaimana proses berpikir kreatif siswa. Menurut Mahmudi (2010) dengan memberikan masalah-masalah yang menantang dapat mendorong siswa tidak mudah menyerah dan tekun. Memberikan siswa memperbaiki jawaban adalah hal biasa, yang terpenting adalah bagaimana upaya dalam meperbaikinya.

\section{KESIMPULAN}

Keterampilan siswa merupakan hal yang tidak hanya kita nilai, tetapi keterampilan tersebut butuh kita pelajari lebih mendalam. Menurut Siswono (2004) kemampuan berpikir kreatif siswa tidak hanya dideskripsikan melalui tingkatan pada respon yang diberikan tanpa melihat sudut pandang yang lain. Berpikir kreatif adalah keterampilan yang penting dimiliki oleh setiap orang. Dalam pembelajaran matematika, peneliti maupun guru dapat melakukan banyak hal terkait dengan kemampuan tersebut. Peneliti dan guru dapat menyusun perbandingan ataupun dapat melihat faktor lain dalam berpikir kreatif seperti prestasi belajar, jenis kelamin, atau faktor lainnya. Guru bisa memberikan kesempatan lebih pada siswa dalam mengeksplorasi berbagai macam respon dengan memperhatikan aspek kelancaran, keaslian, dan kerincian. 
Penelitian berfokus pada proses kemampuan berpikir kreatif siswa. Siswa dibiasakan diberikan soal dengan lebih dari satu jawaban benar atau lebih dari satu strategi yang dapat digunakan untuk menyelesaikan suatu masalah. Melalui masalah open-ended peneliti menyusun pola pikir kreatif siswa dan hasil berpikir kreatif siswa.

Penelitian ini merupakan salah satu cara untuk mengetahui proses berpikir kreatif siswa. Perlu dilakukan penelitian lebih lanjut untuk memperdalam serta dapat menambah kategori berpikir kreatif siswa, tidak hanya kategori tinggi, sedang, rendah. subjek penelitian ini dilakukan pada siswa SMP, perlu dilakukan penelitian pada jenjang lain untuk melihat perbedaan respon siswa secara lebih lanjut.

\section{UCAPAN TERIMAKASIH}

Ucapan terimakasih diberikan kepada Bapak Susiswa dan Bapak I Made Sulandra selaku dosen pembimbing yang telah memeberikan bimbingan dan arahannya dalam proses pembuatan artikel ini. Terimakasih juga ditujukan kepada kepala sekolah SMP An-Nur Bululawang telah memberikan izin untuk melakukan penelitian terhadap siswi-siswinya. Kemudian ucapan terimakasih ditujukan kepada orangtua dan para sahabat yang telah mendukukng dan memberikan semangat.

\section{REFERENSI}

Anderson, L, W. and Krathwohl, R, D. (1956) A Taxonomy for Learning, Teaching, and Assessing (A Revision of Bloom's Taxonomy of Educational Objectives), New York: Pearson Education. doi: $10.2307 / 2281462$.

Bulkova, K. and Ceretkova, S. (2017) 'Rubrics as assessment tool of mathematical open-ended problems', 16th Conference on Applied Mathematics, APLIMAT 2017 - Proceedings, (July 2019), pp. 235-245.

Fajriah, N. and Asiskawati, E. (2015) 'Kemampuan Berpikir Kreatif Siswa dalam Pembelajaran Matematika Menggunakan Pendekatan Pendidikan Matematika Realistik di SMP', EDU-MAT: Jurnal Pendidikan Matematika, 3(2), pp. 157-165. doi: 10.20527/edumat.v3i2.64.

Febrianti, Y., Djahir, Y. and Fatimah, S. (2016) 'Analisis Kemampuan Berpikir Kreatif Peserta Didik dengan Memanfaatkan Lingkungan pada Mata Pelajaran Ekonomi di SMA Negeri 6 Palembang', Jurnal Profit, 3(1), pp. 121-127.

Hamza, M. and Griffith, K. (2006) 'Fostering Problem-Solving and Creative Thinking in The Classroom: Cultivating a Creative Mind', National Forum of Applied, 19(3), pp. 1-30.

Haylock, D. (1997) 'Recognising Mathematical Creativity in Schoolchildren', Zentralblatt fuer Didaktikder Mathematik, 3(29).

Hudojo, H. (2005) Pengembangan Kurikulum dan Pembelajaran Matematika. Malang: UM Press.

Isaksen, S. G., Puccio, G. J. and Treffinger, D. J. (1993) 'An Ecological Approach to Creativity Research: Profiling for Creative Problem Solving', The Journal of Creative Behavior, 27(3), pp. 149-170. doi: 10.1002/j.2162-6057.1993.tb00704.x.

Keh, L. K., Ismail, Z. and Yusof, Y. M. (2019) 'A Review of Open-Ended Mathematical Problem', 
Proses Kemampuan Berpikir Kreatif Siswa Matematika Berdasarkan Masalah Open-Ended pada Materi Bangun Datar, Dian

Anatolian Journal of Education, 1(1), pp. 1-18. doi: 10.29333/aje.2016.111a.

Krulik, S. and Rudnick, J. A. (1995) The New Sourcebook for Teaching Reasoning and Problem Solving in Elementary School. Needham Heights: Allyn \& Bacon.

Magelo, C., Hulukati, E. and Djakaria, I. (2019) 'Pengaruh Model Pembelajaran Open-Ended terhadap Kemampuan Berpikir Kreatif Matematik Ditinjau dari Motivasi Belajar', Jambura Journal of Mathematics, 2(1), pp. 15-21. doi: 10.34312/jjom.v2i1.2593.

Mahmudi, A. (2010) 'Mengukur Kemampuan Berpikir Kreatif Matematis, Makalah dipersentasikan', Seminar Nasional Matematika XV.

Putri, V. S. R. and Wijayanti, P. (2013) 'Identifikasi Tingkat Kemampuan Berpikir Kreatif (TKBK) Siswa Dalam Menyelesaikan Soal Open Ended Pada Materi Segiempat Di Kelas VIII SMP', Jurnal Ilmiah Pendidikan Matematika, pp. 98-103.

Silver, E. A. (1997) 'Fostering Creativity through Instruction Rich in Mathematical Problem Solving and Problem Posing', ZDM - International Journal on Mathematics Education, 29(3), pp. 75-80. doi: 10.1007/s11858-997-0003-x.

Siswono, T. (2004) 'Identifying Creative Thinking Process of Students Through Mathematics Problem', International Conference on Statics and Mathematics.

Sriraman, B., Yaftian, N. and Lee, K. H. (2011) 'Mathematical Creativity and Mathematics Education', The Elements of Creativity and Giftedness in Mathematics, (January), pp. 119-130. doi: 10.1007/978-94-6091-439-3_8. 